\title{
Burkholderia paludis sp. nov., an Antibiotic-Siderophore Producing Novel Burkholderia cepacia Complex Species, Isolated from Malaysian Tropical Peat Swamp Soil
}

OPEN ACCESS

Edited by:

Tzi Bun Ng,

The Chinese University of Hong Kong,

China

Reviewed by:

Vishvanath Tiwari,

Central University of Rajasthan, India

Dinesh Sriramulu,

Shres Consultancy (Life Sciences),

India

Sarah Victoria Harding,

Defence Science and Technology

Laboratory, UK

Sunil D. Saroj,

Stockholm University, Sweden

*Correspondence:

Sui Mae Lee

lee.sui.mae@monash.edu

Specialty section:

This article was submitted to Antimicrobials, Resistance and Chemotherapy,

a section of the journal

Frontiers in Microbiology

Received: 07 September 2016 Accepted: 06 December 2016 Published: 21 December 2016

Citation:

Ong KS, Aw YK, Lee LH, Yule CM

Cheow YL and Lee SM (2016) Burkholderia paludis sp. nov., an Antibiotic-Siderophore Producing

Novel Burkholderia cepacia Complex

Species, Isolated from Malaysian

Tropical Peat Swamp Soil.

Front. Microbiol. 7:2046.

doi: 10.3389/fmicb.2016.02046

\section{Kuan Shion Ong ${ }^{1,2}$, Yoong Kit Aw ${ }^{1,2}$, Learn Han Lee ${ }^{3,4}$, Catherine M. Yule ${ }^{1,2}$, Yuen Lin Cheow ${ }^{1}$ and Sui Mae Lee ${ }^{1,2 *}$}

\footnotetext{
${ }^{1}$ School of Science, Monash University Malaysia, Bandar Sunway, Malaysia, ${ }^{2}$ Tropical Medicine and Biology Multidisciplinary Platform, Monash University Malaysia, Bandar Sunway, Malaysia, ${ }^{3}$ Novel Bacteria and Drug Discovery Research Group, School of Pharmacy, Monash University Malaysia, Bandar Sunway, Malaysia, ${ }^{4}$ Center of Health Outcomes Research and Therapeutic Safety (Cohorts), School of Pharmaceutical Sciences, University Phayao, Phayao, Thailand
}

A novel Gram negative rod-shaped bacterium, designated strain $\mathrm{MSh}^{\top}{ }^{\top}$, was isolated from Southeast Pahang tropical peat swamp forest soil in Malaysia and characterized using a polyphasic taxonomy approach. The predominant cellular fatty acids (>10.0\%) were $\mathrm{C}_{16: 0}$ (31.7\%), $\mathrm{C}_{17: 0}$ cyclo $(26.6 \%)$, and $\mathrm{C}_{19: 0}$ cyclo $\omega 8 \mathrm{c}(16.1 \%)$. The polar lipids detected were phosphatidylglycerol, phosphatidylethanolamine, and diphosphatidylglycerol. The predominant ubiquinone was Q-8. This revealed that strain $\mathrm{MSh}^{\top}$ belongs to the genus Burkholderia. The type strain $\mathrm{MSh}^{\top}{ }^{\top}$ can be differentiated from other Burkholderia cepacia complex (Bcc) species by phylogenetic analysis of 16S rRNA gene sequence, multilocus sequence analysis (MLSA), average nucleotide identity (ANI) and biochemical tests. DNA-DNA relatedness values between strain MSh1 ${ }^{\top}$ and closely related type strains were below the $70 \%$ threshold value. Based on this polyphasic study of $\mathrm{MSh}^{\top}$, it can be concluded that this strain represents a novel species within the Bcc, for which the name Burkholderia paludis sp. nov. is proposed. The type strain is $\mathrm{MSh}^{\top}{ }^{\top}\left(=\mathrm{DSM} 100703^{\top}=\mathrm{MCCC} 1 \mathrm{~K}^{\top} 1245^{\top}\right)$. The dichloromethane extract of $\mathrm{MSh}^{\top}{ }^{\top}$ exhibited antimicrobial activity against four Gram positive bacteria (Enterococcus faecalis ATCC 29212, E. faecalis ATCC 700802, Staphylococcus aureus ATCC 29213, S. aureus ATCC 700699) and a Gram negative bacteria (Escherichia coli ATCC 25922). Further purification work has led to the isolation of Compound 1 , pyochelin. Pyochelin demonstrated antimicrobial activity against four $S$. aureus strains and three $E$. faecalis strains with MIC-values of $3.13 \mu \mathrm{g} / \mathrm{ml}$ and $6.26 \mu \mathrm{g} / \mathrm{ml}$, respectively. SEM analysis showed that the cellular morphology of E. faecalis ATCC 700802 was not affected by pyochelin; suggesting that it might target the intracellular components. Pyochelin, a siderophore with antimicrobial activity might be useful in treating bacterial infections caused by S. aureus and E. faecalis, however further work has to be done.

Keywords: antimicrobial, Burkholderia cepacia complex, multilocus sequence analysis (MLSA), polyphasic taxonomy, tropical peat swamp forest 


\section{INTRODUCTION}

The misuse of antimicrobial compounds to treat infections has led to an increase in the prevalence of antimicrobial resistant bacteria (ARB), often associated with nosocomial (hospital acquired) infections (Mishra et al., 2012). It was reported that nosocomial infections constitute the sixth leading cause of death in the United States and more than $70 \%$ of these nosocomial pathogens are resistant to at least one of the common antimicrobial drugs used to treat them (Iowa Department of Public Health). This is an alarming issue because ARB infections often result in increased mortality rates, limit treatment options and cause increased healthcare costs (Ammerlaan et al., 2016). Thus, there is a need for new antimicrobial compounds to combat ARB infections.

One strategy to discover new antimicrobials is bioprospecting-the exploration for new compounds in unique ecological niches (Imhoff et al., 2011). The discovery of abyssomicins, novel antibiotics produced by Verrucosispora sp. from South China Sea sediments is a successful example of bioprospecting (Wang et al., 2013). Bacteria producing antibiotics may have an advantage in competing for resources and colonization of new habitats in natural environments. Novel microorganisms thriving in extreme and isolated environments have the potential to develop unique biosynthesis gene clusters giving rise to novel compounds (Bull and Stach, 2007; Hibbing et al., 2010). Consequently, tropical peat swamp forests in Malaysia were chosen as potential bioprospecting locations for novel antimicrobial compounds. Tropical peat swamp forests are unique wetland ecosystems characterized by their acidic ( $\mathrm{pH}$ range of 2.9 to 4.5 ) and waterlogged conditions. They are ombotrophic hence receiving nutrients solely from rain and atmospheric deposition which results in an extremely nutrient poor environment (Yule, 2010). Despite being such a harsh environment, we successfully isolated an antimicrobialproducing bacterium, belonging to the Burkholderia cepacia complex (Bcc) in a previous study (Ong et al., 2015).

The Bcc consists of a group of diverse, ubiquitous bacteria that occur in aquatic environments, plant rhizospheres and animals, including humans (Coenye and Vandamme, 2003; Vanlaere et al., 2009; Peeters et al., 2013). Certain Bcc species, for example B. cepacia, can be used for biocontrol as they can produce antifungal compounds to repress soil borne pathogens (Caballero-Mellado et al., 2004). An example of one such compound is pyrrolnitrin which targets the electron transport chain of both Gram positive bacteria and fungi (El-Banna and Winkelmann, 1998). Bcc species share a high degree of $16 \mathrm{~S}$ rRNA (98-100\%) and recA (94-95\%) gene sequence similarity, and moderate levels of DNA-DNA hybridization (30-50\%) (Coenye et al., 2001). In order to differentiate different species of Bcc, multi-locus sequence analysis (MLSA) are usually adopted as these taxonomic techniques provide the discriminatory power needed for both identification and differentiation of Bcc species (Spilker et al., 2009; Vanlaere et al., 2009; Peeters et al., 2013).

Abbreviations: Bcc, Burkholderia cepacia complex; MLSA, multilocus sequence analysis.
In this paper, we report a novel antimicrobial-producing Bcc species, isolated from the peat soil of the Southeast Pahang tropical peat swamp forest reserve in Malaysia. This polyphasic taxonomic study revealed that strain $\mathrm{MSh}^{\mathrm{T}}$ represents a novel Bcc species, for which the name B. paludis is proposed. Based on current literature, Burkholderia species are known to produce narrow-spectrum antimicrobial compounds such as iminopyrrolidines (produced by $B$. plantari) and occidiofungin (B. contaminans) which only targets Gram negative Erwinia amylovora and fungi, respectively (Lu et al., 2009; Tawfik et al., 2010). In this study, strain MSh $1^{\mathrm{T}}$ exhibit a different spectrum of antimicrobial activity, which targets Gram positive bacteria only, particularly strains of $S$. aureus and E. faecalis.

\section{MATERIALS AND METHODS}

\section{Test Microorganism Strains and Culture Conditions}

Test microorganism strains that were used in this study include Bacillus cereus ATCC 14579, Bacilus subtilis ATCC 8188, Enterococcus faecalis ATCC 700802, Enterococcus faecalis ATCC 29212, Enterococcus faecalis JH-22, Staphylococcus aureus ATCC 700699, Staphylococcus aureus ATCC 43300, Staphylococcus aureus ATCC 6538P, Staphylococcus aureus ATCC 29213, Aeromonas hydrophila ATCC 49140, Escherichia coli ATCC 25922, Klebsiella pneumoniae ATCC 10031, Proteus mirabilis ATCC 49140, Proteus vulgaris (Institute of Medical Research, Malaysia), Pseudomonas aeruginosa ATCC 10145, Pseudomonas aeruginosa ATCC BAA-47, Salmonella Typhimurium ATCC 14028, and Shigella flexneri ATCC 12022. Strains were cultured on Muller Hinton borth (MHB) (Oxoid, UK) at $37^{\circ} \mathrm{C}$ and maintained at $-80^{\circ} \mathrm{C}$ in $\mathrm{MHB}$ with $25 \%$ (v/v) glycerol.

\section{Isolation and Maintenance of Isolate}

Strain $M S h 1^{\mathrm{T}}$ was previously isolated from surface peat collected from the Southeast Pahang tropical peat swamp forest reserve $\left(3^{\circ} 01^{\prime} 19.56^{\prime \prime} \mathrm{N} ; 103^{\circ} 39^{\prime} 29.67^{\prime \prime} \mathrm{E}\right)$ in Malaysia on March 2013. Strain $\mathrm{MSh} 1^{\mathrm{T}}$ was maintained on nutrient agar (NA) at $30^{\circ} \mathrm{C}$ and in $25 \%(\mathrm{v} / \mathrm{v})$ glycerol in nutrient broth (NB) (Merck, Germany) at $-80^{\circ} \mathrm{C}$ for long term preservation.

\section{Sequence and Phylogenetic Analysis}

The genomic DNA of strain $\mathrm{MSh}^{\mathrm{T}}$ was isolated using GF-1 nucleic acid extraction kit (Vivantis, Malaysia). The 16S rRNA gene sequence of strain $M S h 1^{\mathrm{T}}$ was amplified using the universal primers 27f (5'-AGA GTT TGA TCC TGG CTC AG-3') and 1492r (5'-ACG GCT ACC TTG TTA CGA CTT 3') (Kane et al., 1993). PCR were set up as follows: $150 \mathrm{ng}(5 \mu \mathrm{L})$ of DNA extract, $10 \mu \mathrm{L}$ of $5 \mathrm{x}$ MyTaq Red Reduction Buffer, $5 \mu \mathrm{M}$ of forward primer, $5 \mu \mathrm{M}$ of reverse primer, and $1.25 \mathrm{U}$ of MyTaq DNA polymerase. The reaction volume was made up to $50 \mu \mathrm{L}$ using sterile milliQ water (Millipore, Germany). The PCR included an initial denaturation step at $95^{\circ} \mathrm{C}$ for $1 \mathrm{~min}$, followed by 30 cycles of denaturation at $95^{\circ} \mathrm{C}$ for $15 \mathrm{~s}$, annealing at $60^{\circ} \mathrm{C}$ for $45 \mathrm{~s}$ and elongation at $72^{\circ} \mathrm{C}$ for $45 \mathrm{~s}$. PCR products were separated on a $1.5 \%(\mathrm{w} / \mathrm{v})$ agarose gel and the bands were visualized with 1x GelRed. Amplification products were purified 
and cloned into pJET1.2 vector (FirstBase, Malaysia). The 16S rRNA gene sequence of strain MSh $1^{\mathrm{T}}$ was aligned with sequences of closely related type strains of the genus Burkholderia retrieved from the GenBank/EMBL/DDBJ databases using CLUSTAL-X software (Thompson et al., 1997). The alignment was manually verified and adjusted prior to the construction of phylogenetic tree using the neighbor-joining (Saitou and Nei, 1987) algorithm with the MEGA version 6.0 software (Tamura et al., 2011). The stability of the resultant tree topologies were evaluated by using the bootstrap resampling method (Felsenstein, 1985). The evolutionary distances for the neighbor-joining algorithm were computed using the Kimura's two-parameter model (Kimura, 1980).

\section{DNA-DNA Hybridization (DDH)}

DDH-tests were carried out by the Identification Service of Deutsche Sammlung von Mikroorganisen und Zellkulturen (DSMZ, Germany) to evaluate the DNA-DNA relatedness between strain $\mathrm{MSh}^{\mathrm{T}}$, B. arboris $\mathrm{R}-24201^{\mathrm{T}}$, B. cenocepacia $\mathrm{J} 2315^{\mathrm{T}}$, and $B$. lata $383^{\mathrm{T}}$ using the optical renaturation rate method as described by De Ley et al. (1970) under consideration of the modifications described by Huss et al. (1983).

\section{Multilocus Sequence Analysis (MLSA)}

MLSA was performed on strain MSh1 $1^{\mathrm{T}}$ based on the method described by Spilker et al. (2009). A phylogenetic tree of the concatenated sequence (2773 bp) of seven housekeeping gene fragments [atpD (443 bp), glt $\mathrm{B}(400 \mathrm{bp}), \operatorname{gyr} \mathrm{B}(454 \mathrm{bp}), \operatorname{rec} \mathrm{A}$ (393 bp), lepA (397 bp), phaC (385 bp) and $\operatorname{trp} \mathrm{B}(301 \mathrm{bp})]$ was constructed using MEGA6.0 (Tamura et al., 2011). The mean number of nucleotide substitution per site (i.e., the percentage of divergence of concatenated allele sequences) between established Bcc type strains and strain $\mathrm{MSh}^{\mathrm{T}}$ was calculated using the DnaSP v5.10 (Librado and Rozas, 2009) based on the JukesCantor method (Jukes and Cantor, 1969). Nucleotide sequences of each allele, allelic profiles and sequence types of strain MSh1 $1^{\mathrm{T}}$ from the present study are available on the Bcc PubMLST database (http://pubmlst.org/bcc).

\section{PCR Amplification of prnD (Pyrrolnitrin) Gene}

The synthesis of pyrrolnitrin is regulated mainly by four genes $p r n A, p r n B, p r n C$ and $p r n D$, where $p r n D$ being the most crucial gene. The gene product of $p r n D$ catalyzes the oxidation of the amino group of aminopyrrolnitrin to a nitro group to form pyrrolnitrin (Souza and Raaijmakers, 2003). As pyrrolnitrin is the only reported compound with antimicrobial activity against Gram positive bacteria known to be produced by Bcc (El-Banna and Winkelmann, 1998), this assay was carried out to avoid the rediscovery of a known compound (pyrrolnitrin). Hence in order to assess the ability of strain $M S h 1^{\mathrm{T}}$ to produce pyrrolnitrin, the $\operatorname{prn} D$ gene was amplified with a forward primer PRND1 (5'-GGG GCG GGC CGT GGT GAT GGA-3') and a reverse primer PRND2 (5'-YCC CGC SGC CTG YCT GGT CTG-3') (Souza and Raaijmakers, 2003). PCR were set up as follows: 5 $\mu \mathrm{L}$ of DNA extract, $10 \mu \mathrm{L}$ of $5 \mathrm{x}$ MyTaq Red Reduction Buffer, $5 \mu \mathrm{M}$ of forward primer, $5 \mu \mathrm{M}$ of reverse primer, and $1.25 \mathrm{U}$ of MyTaq DNA polymerase. The reaction volume was made up to $50 \mu \mathrm{L}$ using sterile milliQ water (Millipore, Germany). The PCR included an initial denaturation step at $95^{\circ} \mathrm{C}$ for $1 \mathrm{~min}$, followed by 30 cycles of denaturation at $95^{\circ} \mathrm{C}$ for $60 \mathrm{~s}$, annealing at $68^{\circ} \mathrm{C}$ for $30 \mathrm{~s}$, and elongation at $72^{\circ} \mathrm{C}$ for $30 \mathrm{~s}$. Genomic DNA of pyrrolnitrin producer $B$. lata $383^{\mathrm{T}}$ was used as a positive control and non-pyrrolnitrin producer $B$. cenocepacia $\mathrm{J} 2315^{\mathrm{T}}$ was used as a negative control. PCR products were separated on a $1.5 \%(\mathrm{w} / \mathrm{v})$ agarose gel and the bands were visualized with 1x GelRed.

\section{Phenotypic and Biochemical Characterization}

Cellular morphological characteristics of strain $\mathrm{MSh}^{\mathrm{T}}$ were observed by using a Hitachi S- 4800 field-emission scanning electron microscopy (FE-SEM) at 25,000 $\times$ magnification after 2 days of growth in nutrient broth $(\mathrm{NB})$ at $30^{\circ} \mathrm{C}$. Colony morphology of strain $M S h 1^{\mathrm{T}}$ was examined after 2 days of growth on NA at $30^{\circ} \mathrm{C}$. Cell motility was measured using hanging drop method after incubation for 2 days at $30^{\circ} \mathrm{C}$ in NB (Robbie, 1945). The optimal temperature for growth was measured at 4, 15, $28,30,37,40$, and $45^{\circ} \mathrm{C}$ in $\mathrm{NB}$ for 2 days. The $\mathrm{pH}$ range for growth was tested with in $\mathrm{NB}$ adjusted with $\mathrm{HCl}$ or $\mathrm{NaOH}$ to $\mathrm{pH} 3-11$, at intervals of $0.5 \mathrm{pH}$ units. $\mathrm{NaCl}$ tolerance at $0-5 \%$ $(\mathrm{w} / \mathrm{v})$ at interval of $0.5 \%(\mathrm{w} / \mathrm{v})$ was determined in NB for 2 days. Anaerobic growth was tested in NB for up to 5 days in a 2.51 jar containing an AnaeroPack-Anaero (Thermo Scientific, USA). Phenotypic characteristics including Gram staining, catalase, and oxidase activity were examined using the methods described by Buck (1982) and Cappuccino and Sherman (2002) after 2 days of growth on NA at $30^{\circ} \mathrm{C}$. Physiological and biochemical properties were further determined using API 50CH, API 20NE, and API ZYM strips (bioMerieux, France) according to the manufacturer's instructions. All tests were conducted in duplicate. The API $50 \mathrm{CH}$ and API $20 \mathrm{NE}$-tests were read after $24-48 \mathrm{~h}$ at $30^{\circ} \mathrm{C}$, while the API ZYM-tests were read after $4 \mathrm{~h}$ of incubation at $30^{\circ} \mathrm{C}$.

\section{Chemotaxonomic Characterization}

The cellular fatty acids analysis of strain $\mathrm{MShl}^{\mathrm{T}}, B$. arboris $\mathrm{R}$ $24201^{\mathrm{T}}$, B. cenocepacia $\mathrm{J} 2315^{\mathrm{T}}$, and B. lata $383^{\mathrm{T}}$ was carried out by the Identification Service of DSMZ (Braunschweig, Germany). The cell mass of strain $\mathrm{MSh}^{\mathrm{T}}$ and closely related type strains were harvested from NB after incubation at $30^{\circ} \mathrm{C}$ for 2 days. Extraction and analysis of the cellular fatty acids were performed according to the standard protocols of the Sherlock Microbial Identification System (MIDI) (Miller, 1982), analyzed using an Agilent $6890 \mathrm{~N}$ gas chromatograph fitted with a $5 \%$ phenylmethyl silicone capillary column. Peaks were integrated and identified using the peak-naming table TSBA40 at the DSMZ. Polar lipids extracted from $200 \mathrm{mg}$ freeze-dried cell material using chloroform: methanol: $0.3 \%(\mathrm{w} / \mathrm{v})$ aqueous $\mathrm{NaCl}$ mixture 1:2:0.8 (v/v/v) as described by Tindall (1990). The extracted polar lipids were then separated by two dimensional silica gel thin layer chromatography with chloroform: methanol: water $(65: 25: 4, \mathrm{v} / \mathrm{v} / \mathrm{v})$ as mobile phase for the first direction, followed by chloroform: methanol: acetic acid: water (80:12:15:4, v/v/v/v) as the mobile phase for the second direction (Tindall et al., 2007). Cellular ubiquinones were extracted and purified as 
described previously by Tindall (1990). The different quinone classes were firstly separated using thin layer chromatography on silica gel using hexane-tert-butylmethylether $(9: 1, \mathrm{v} / \mathrm{v})$ as a solvent and then further purified with reversed-phase HPLC using methanol:heptane $(9: 1, \mathrm{v} / \mathrm{v})$ as the eluent. The purified quionones were compared to standards at the DSMZ.

\section{Genome-To-Genome Distance Calculator (GGDC) and Average Nucleotide Identity}

\section{(ANI)}

GGDC was performed to predict the DNA-DNA hybridization value between strain $\mathrm{MSh}^{\mathrm{T}}$ with related Burkholderia species. GGDC was performed at http://ggdc.dsmz.de/distcalc2.php using the standard parameters (GGDC 2.0 BLAST+) (MeierKolthoff et al., 2013). The genome sequence of strain MSh1 ${ }^{\mathrm{T}}$ (DDBJ/EMBL/GenBank JPGL00000000) (Ong et al., 2014) was queried with related Bcc species. Results were expressed as similarity percentage \pm confidence interval. ANI was performed to estimate the mean values between homologous genomic regions shared by strain $M S h 1^{\mathrm{T}}$ with related Bcc species using the whole genome sequence obtained. ANI was performed at http:// enve-omics.ce.gatech.edu/ani using the standard parameters (Goris et al., 2007). Results were expressed as ANI percentage \pm standard deviation.

\section{Genome Analysis of Secondary Metabolites Gene Clusters Using Antismash}

The whole genome of strain MSh $1^{\mathrm{T}}$ was screened for biosynthetic gene clusters responsible for the synthesis of secondary metabolites using Antibiotics and Secondary Metabolite Analysis Shell (antiSMASH) 2.0) (Blin et al., 2013). The antiSMASH 2.0 program analyses the whole genome sequence for homologs to known secondary metabolites via BLAST search and annotates them based on different biosynthetic gene clusters, for example polyketide synthase (PKS), non-ribosomal peptide synthase (NRPS), terpene and bacteriocins.

\section{Methanol Extraction of MSh1 ${ }^{\top}$}

Strain $M S h 1^{\mathrm{T}}$ was first grown on nutrient agar supplemented with $5 \mathrm{~g} / \mathrm{l}$ of glycerol for 5 days at $30^{\circ} \mathrm{C}$. The whole agar including the bacteria was extracted three times with $100 \%$ methanol (Merck, Germany) (Isnansetyo and Kamei, 2003). The crude methanol extract was lyophilized using a Freezone 4.5 Plusfreeze Dryer (Labconco, USA).

\section{Sequential Solvent Fractionation and Purification of the Crude Methanol Extract}

Sequential solvent fractionation was performed on the crude methanol extract to fractionate the extract into different fractions with different polarity. Five grams of crude methanol extract was first dissolved in $500 \mathrm{ml}$ of distilled water, and then extracted with hexane (HEX), dichloromethane (DCM) and ethyl acetate (EtOAc) sequentially. Each extraction step was performed three times and combined into one fraction before lyophylization in a Freezone 4.5 Plusfreeze dryer (Labconco, USA). The lyophilized active fraction was dissolved in methanol and partially purified on an open $\mathrm{C}_{18}$ column (Merck, Germany), followed by reversedphase HPLC using a Cosmosil 5C18-MS-II, $20 \times 250 \mathrm{~mm}, 5 \mu \mathrm{m}$ column (Nacalai, USA), to yield compound 1. All processes were monitored by bioassay.

\section{Identification of the Antimicrobial Compound(s) from Strain MSh1 ${ }^{\top}$}

Structural determination of the antimicrobial compound was performed by spectroscopic techniques and literature comparison. The antimicrobial compound was analyzed by thinlayer chromatography on a silica 60 plates (Merck, Germany) with chloroform-acetic acid-ethanol at 95:5:2.5 (v/v) as the mobile phase, followed by spraying of an iron reagent $(0.1 \mathrm{M}$ $\mathrm{FeCl}_{3}$ in $0.1 \mathrm{M} \mathrm{HCl}$ ). LC-MS was performed with an Agilent 1290 Infinity LC system coupled to Agilent 6520 Accurate-Mass Q-TOF mass spectrometer (dual ESI source) equipped with an Agilent Zorbax Eclipse XDB-C18 column. The ultraviolet/visible absorption spectrum was recorded with the photodiode array detector equipped with the above-mentioned HPLC. The mobile phase was composed of water (A, $0.5 \%$ formic acid) and acetonitrile (B, $0.5 \%$ formic acid), the gradient program of which was $0-12.00 \mathrm{~min} 90 \% \mathrm{~A}$ and $10 \% \mathrm{~B}$ and $12.00-15.00 \mathrm{~min} 100 \%$ B. The follow rate of the mobile phase was $0.3 \mathrm{ml} / \mathrm{min}$, and the column temperature was set to $25^{\circ} \mathrm{C}$. The injection volume was $10 \mu \mathrm{l}$.

\section{Antimicrobial Testing Via Broth Microdilution}

The antimicrobial activity of each fraction was evaluated using a broth microdilution assay to determine the minimum inhibitory concentration (MIC) of an antimicrobial compound as described by the Clinical and Laboratory Standard Institute (CLSI). MIC is defined as the lowest concentration of an antimicrobial to inhibit the visible growth of a microorganism after overnight incubation. Briefly, the test microorganisms were grown in $\mathrm{MHB}$ at $37^{\circ} \mathrm{C}$ for $24 \mathrm{~h}$ and adjusted to $0.5 \mathrm{McF}$ arland standard $\left(\mathrm{OD}_{625}\right.$ 0.08-0.11). The adjusted cultures were then diluted 100 times in MHB and used as inocula. The extracts were serially diluted using sterile MHB in a 96-well flat bottomed microtiter plate. One hundred micro liters of test microorganisms corresponding to approximately $10^{5}$ colony forming units (CFU) was added to each well. Determination of MIC was performed in triplicate. The positive control for bacteria was $100 \mu \mathrm{g} / \mathrm{ml}$ chloramphenicol. The negative control contained MHB with test microorganisms. The blank control consisted only of MHB. The microtiter plate was incubated at $37^{\circ} \mathrm{C}$ aerobically for $24 \mathrm{~h}$ and the MIC was determined by the concentration of extract $(\mu \mathrm{g} / \mathrm{ml})$ where no visible growth was observed.

\section{Scanning Electron Microscopy (SEM)}

SEM was performed based on the method described by Pilsczek et al. (2010) with modification, to determine the effect of the extract on the cellular morphology of the bacteria. E. faecalis ATCC 700802 was grown in $\mathrm{MHB}$ at $37^{\circ} \mathrm{C}$ for $24 \mathrm{~h}$ and the turbidity was adjusted to $0.5 \mathrm{McF}$ arland standard. The MIC of the extract was added to the adjusted bacterial culture. An untreated control was used as a negative control, while treatment with $100 \mu \mathrm{g} / \mathrm{mL}$ chloramphenicol was used as the positive control. 
All samples were incubated at $37^{\circ} \mathrm{C}$ for $4 \mathrm{~h}$. The cultures were then centrifuged at $5000 \times g$ for $3 \mathrm{~min}$ and the supernatant was discarded. The bacterial pellet was washed with phosphate buffered saline $(\mathrm{PBS})$ and subjected to centrifugation at $5000 \times \mathrm{g}$ for $3 \mathrm{~min}$. This washing process was repeated three times. The washed pellets were reconstituted in minimal volume of PBS, placed onto glass slides $(5 \times 5 \mathrm{~mm})$ and allowed to air dry for $30 \mathrm{~min}$. The slides were fixed using $2.5 \%(\mathrm{v} / \mathrm{v})$ gluteraldehyde in PBS for $4 \mathrm{~h}$ and washed three times with PBS to remove excess glutaraldehyde. The slides were then serially dehydrated with increasing concentration of ethanol and kept in a desiccator overnight. The slide was spur-coated with platinum using Q150R rotary-pumped sputter coater before observed using SU8010 FE-SEM (Hitachi, Japan).

\section{Nucleotide Sequence Accession Number}

The 16s rRNA gene sequence of strain $\mathrm{MSh}^{\mathrm{T}}$ has been deposited in GenBank/EMBL/DDBJ under the accession number KT159931. The gene sequences of each MLSA loci have been deposited at the Bcc PubMLST database with sequence typing (ST) 1043; and GenBank/EMBL/DDBJ under the accession number KU301866-301872.

\section{RESULTS}

\section{$16 S$ rRNA Gene Sequence Analysis}

The 16S rRNA gene sequence was obtained for strain $\mathrm{MSh}^{\mathrm{T}}$ (1497 bp; GenBank/EMBL/DDBJ accession number KT159931) and a phylogenetic tree was constructed (Figure 1). Phylogenetic analysis demonstrated that strain $\mathrm{MSh}^{\mathrm{T}}$ is closely related to $B$. arboris $\mathrm{R}-24201^{\mathrm{T}}$ and $B$. lata $383^{\mathrm{T}}$, as they formed a distinct clade (Figure 1). Pairwise comparison of the 16S rRNA gene sequence of strain $\mathrm{MSh}^{\mathrm{T}}$ with those Bcc type strains revealed similarity levels between 97.1 and $99.9 \%$ (data not shown).

\section{DDH}

The DNA-DNA relatedness values between strain $M S h 1^{\mathrm{T}}$ with its close neighbor based on $16 \mathrm{~S}$ rRNA phylogenetic analysis: B. arboris R- $24201^{\mathrm{T}}(29.0 \pm 3.7 \%)$, B. cenocepacia $\mathrm{J} 2315^{\mathrm{T}}(32.8 \pm$

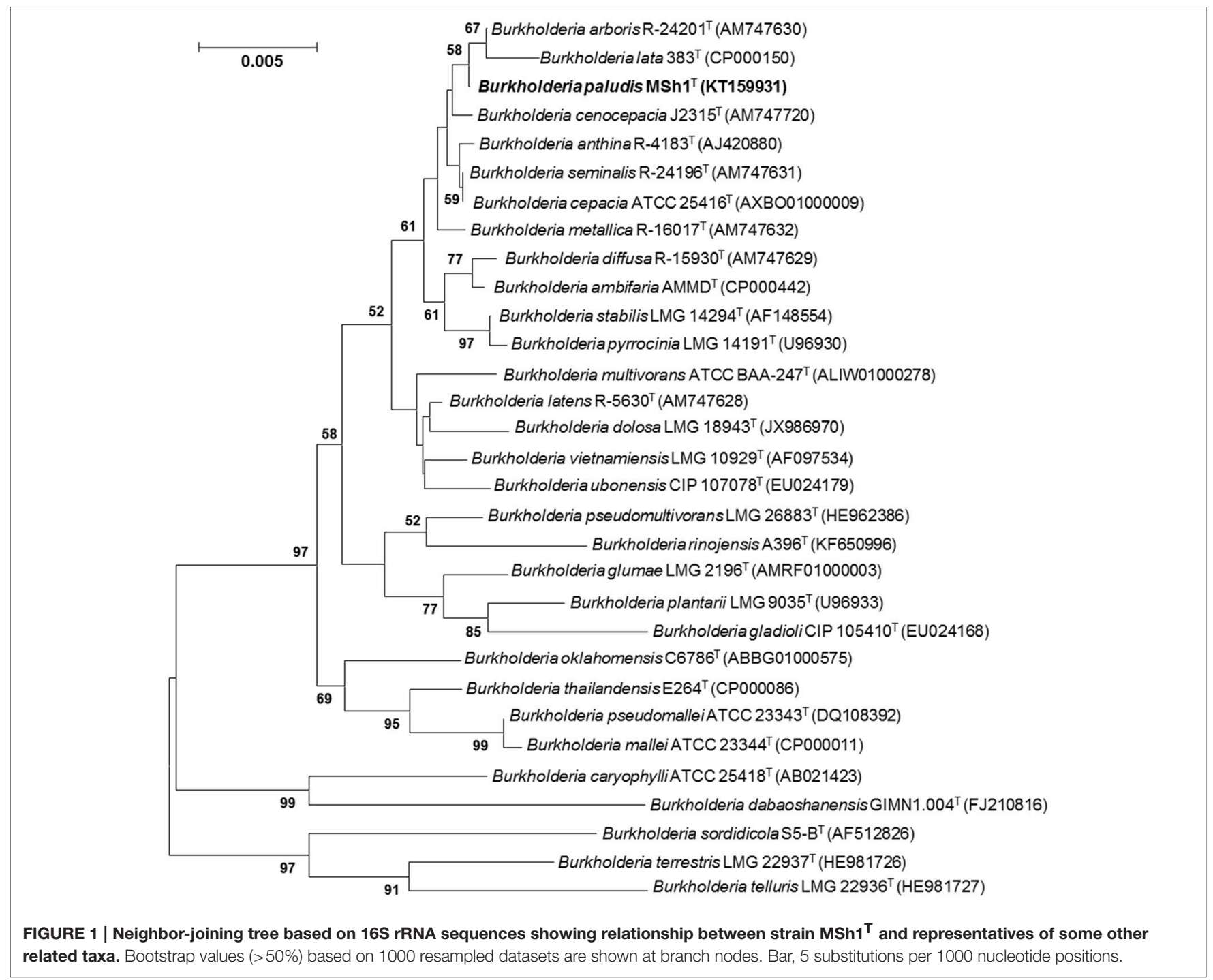


$2.2 \%)$ and B. lata $383^{\mathrm{T}}(19.5 \pm 1.8 \%)$ were significantly below the $70 \%$ threshold value for species delineation (Wayne et al., 1987).

\section{MLSA}

Phylogenetic analysis of concatenated allele sequences demonstrated that strain $\mathrm{MSh}^{\mathrm{T}}$ diverged from the other closely related Bcc type strains, supported by a bootstrap value of $86 \%$ (Figure 2). MLSA data were used to assign allele types and allelic profiles. The allelic profile were as follows: atpD, 302; gltB, 11; gyrB, 50; recA, 350; lepA, 288; phaC, 249; and $\operatorname{trp} B, 345$ (GenBank/EMBL/DDBJ accession number KU301866-301872). Strain $M S h 1^{\mathrm{T}}$ showed distinct allelic profile when compared with those closely related type strains (Table S1). For each established Bcc species, all allele types and allelic profiles were exported from the Bcc MLST database. The average concatenated allele sequence divergence of strain $\mathrm{MSh} 1^{\mathrm{T}}$ toward its nearest neighbor B. stabilis LMG $14294^{\mathrm{T}}(5.23 \%)$, B. pyrrocinia LMG $14191^{\mathrm{T}}$ (5.81\%) and B. cenocepacia IIIC $19230^{\mathrm{T}}$ (6.87\%) were above the $3 \%$ cut-off value hence indicating that strain $M S h 1^{\mathrm{T}}$ is a novel species within the Bcc (Table S2) (Vanlaere et al., 2009; Peeters et al., 2013). Moreover, these data further substantiated the results obtained from DDH which confirmed that strain $M S h 1^{\mathrm{T}}$ is a novel species within the Bcc as the concatenated allele divergences between strain $\mathrm{MSh}^{\mathrm{T}}$ and its close neighbor,

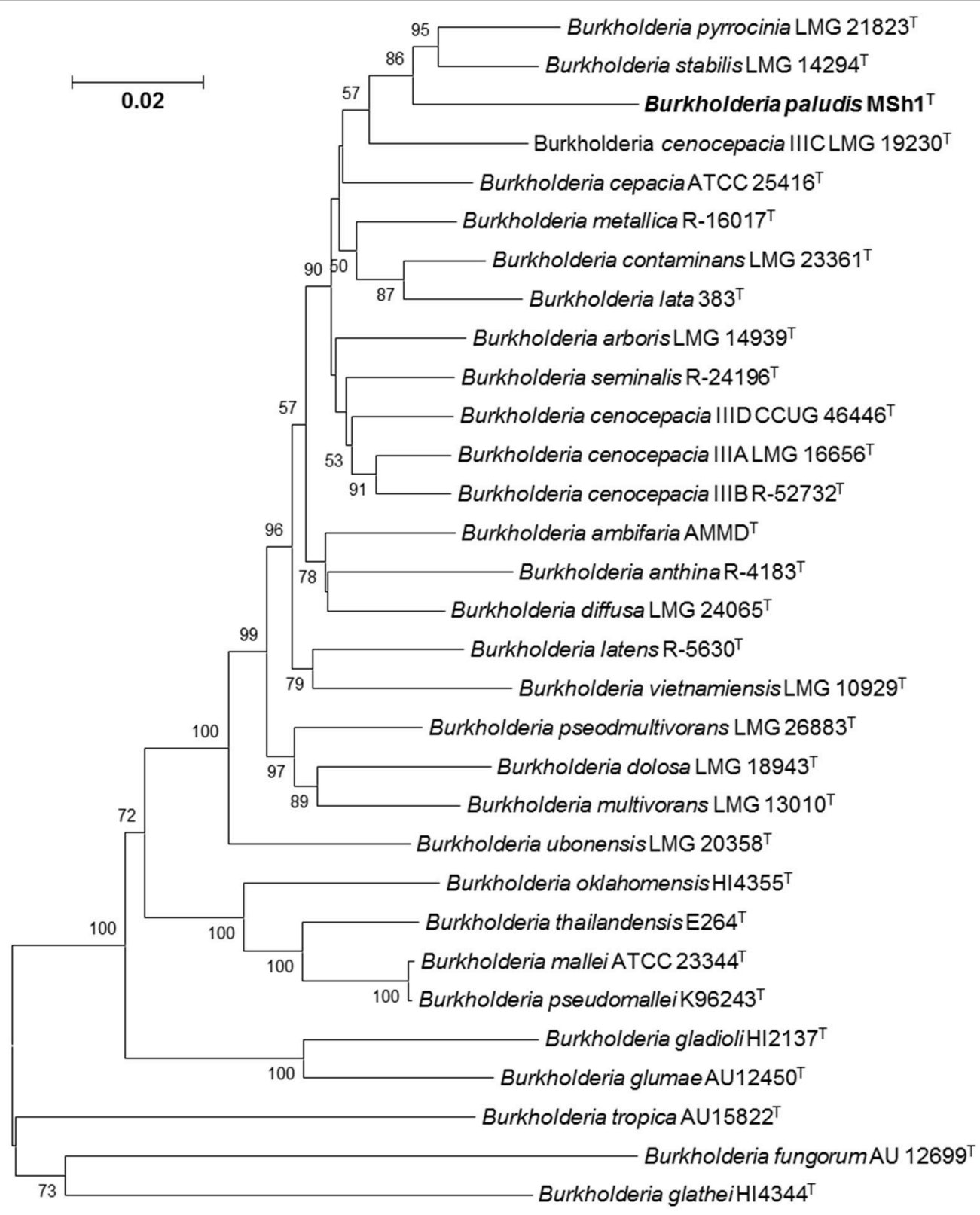

FIGURE 2 | Phylogenetic tree based on the concatenated sequences of seven housekeeping gene fragments of established Bcc species and strain MSh1 ${ }^{\mathbf{T}}$. Bootstrap values (>50\%) based on 1000 resampled datasets are shown at branch nodes. Bar, 2 substitutions per 100 nucleotide positions. 
B. arboris $\mathrm{R}-24201^{\mathrm{T}}$, B. cenocepacia $\mathrm{J} 2315^{\mathrm{T}}$ and B. lata $383^{\mathrm{T}}$ were more than $3 \%$.

\section{Phenotypic and Biochemical Characterization}

Strain MSh1 $1^{\mathrm{T}}$ was Gram negative, facultative anaerobic, motile, rod-shaped, $0.6-0.8 \times 1.6-2.1 \mu \mathrm{m}$ bacterium (Figure 3). Colonies produced by the strain MSh $1^{\mathrm{T}}$ on NA were round, yellow colored with a smooth surface and $2-3 \mathrm{~mm}$ in diameter. Growth of strain $\mathrm{MSh}^{\mathrm{T}}$ occurs at $15-40^{\circ} \mathrm{C}$ (optimum $30^{\circ} \mathrm{C}$ ) and $\mathrm{pH}$ 4.0-10.0 (optimum $\mathrm{pH}$ 7.0) in NB. Growth occurs with $0-2.5 \% \mathrm{NaCl}$ (optimum without $\mathrm{NaCl}$ ). Table 1 shows that strain MSh $1^{\mathrm{T}}$ can be differentiated biochemically from the closely related members of the genus Burkholderia. It was shown that strain MSh $1^{\mathrm{T}}$ differs from the other Bcc species by the ability to acidify adonitol, having arginine dihydrolase activity and inability to assimilate $\mathrm{N}$-acetyl-glucosamine (Vandamme et al., 1997, 2000, 2002; Coenye et al., 2001; Henry et al., 2001; Vanlaere et al., 2008, 2009; Peeters et al., 2013).

\section{Chemotaxonomic Characterization}

Chemotaxonomic analysis revealed that the major cellular fatty acids were $\mathrm{C}_{16: 0}(31.7 \%), \mathrm{C}_{17: 0}$ cyclo $(26.6 \%)$ and $\mathrm{C}_{19: 0}$ cyclo $\omega 8 \mathrm{c}(16.1 \%)$. The fatty acid profile of $\mathrm{MSh}^{\mathrm{T}}$ was consistent with these of closely related type strains such as B. arboris $\mathrm{R}-24201^{\mathrm{T}}$, B. cenocepecia $\mathrm{J} 2315^{\mathrm{T}}$, and B. lata $383^{\mathrm{T}}$ which contained fatty acid $\mathrm{C}_{16: 0}(28.2-36.5 \%), \mathrm{C}_{17: 0}$ cyclo $(22.5-26.1 \%)$ and $\mathrm{C}_{19: 0}$ cyclo $\omega 8$ c (13.7-19.8\%) (Table 1). The ubiquinone Q-8 was detected. The polar lipids consisted phosphatidylglycerol (PG), phosphatidylethanolamine (PE) and diphosphatidylglycerol (DPG), aminolipid and aminophospholipid (Figure 4). The fatty acid profile, polar lipid profile and major isoprenoid quinone of strain MSh $1^{\mathrm{T}}$ were consistent with Burkholderia type strains (Gillis et al., 1995).

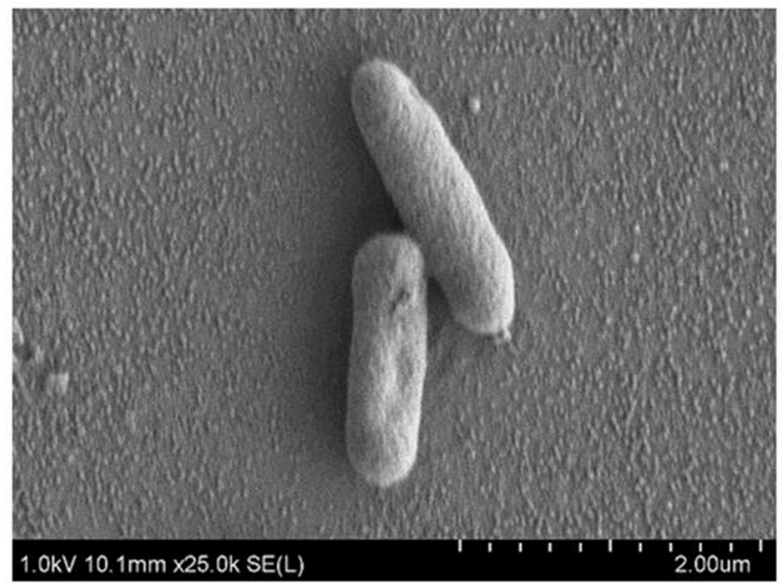

FIGURE 3 | SEM images of Burkholderia paludis MSh1 $^{\top}$. Images were taken under 25,000 $\times$ magnification at $1 \mathrm{kV}$. The bacterial cells sizes are approximately $0.6-0.8 \times 1.6-2.1 \mu \mathrm{m}$.

\section{Genome-To-Genome Distance Calculator (GGDC) and Average Nucleotide Identity (ANI)}

GGDC is an in silico genome-to-genome comparison tool used to calculate the intergenomic distances and relatedness of strain $\mathrm{MSh}^{\mathrm{T}}$ with known type strains (Meier-Kolthoff et al., 2013). The data obtained is converted to similarity values analogous to DNA-DNA hybridization (DDH) hence similarity value of 70\% is generally regarded as a threshold for new species determination (Meier-Kolthoff et al., 2013). It was found that the similarity values between strain $M S h 1^{\mathrm{T}}$ with related known Bcc species are less than $70 \%$, thus suggesting that this isolate might represent new species. This is further supported by the ANI results which revealed that strain $M S h 1^{\mathrm{T}}$ had ANI-value lower than the 96\% threshold for new species (Goris et al., 2007; Table S3).

\section{Genome Analysis of Secondary Metabolites Gene Clusters Using Antismash}

Antimicrobial compounds produced by bacteria are usually secondary metabolites which are regulated by biosynthetic gene clusters. These gene clusters can be annotated using antiSMASH 2.0 (Blin et al., 2013, 2014). Analysis showed that the genome of strain $\mathrm{MSh}^{\mathrm{T}}$ had 43 gene clusters responsible for the biosynthesis of secondary metabolites which include the PKS, NRPS, bacteriocin, and terpene biosynthetic genes. Besides that, it was found that strain $\mathrm{MSh}^{\mathrm{T}}$ (43 gene clusters) possess a higher number of biosynthetic gene clusters compared to other related Burkholderia species ( 9 to 25 gene clusters) despite having similar genome size (Table 2). This might indicate that some of the putative biosynthetic gene clusters might be new as antiSMASH was unable to annotate due to the lack of similarity between query sequences from the database. These results revealed that the antimicrobial compounds produced by strain MSh1 $1^{\mathrm{T}}$ might either be new or under-studied.

\section{Antimicrobial Activity of $\mathrm{MSh}^{\top}$}

The methanol extract of $\mathrm{MSh}^{\mathrm{T}}$ demonstrated antimicrobial activity four Gram positive bacteria and a Gram negative bacterium (Table 3). It was found that the Gram positive bacteria had lower MIC-value when compared to the Gram negative bacteria. Sequential solvent fractionation of the methanol crude extract yielded four different fractions with different polarities (HEX fraction, DCM fraction, EtOAc fraction and water fraction). The DCM fraction showed similar antimicrobial activity (MIC $0.020 \mathrm{mg} / \mathrm{ml}$ ) to the crude methanol extract, indicating that the antimicrobial compounds had successfully been fractionated from the original extract. Further purification of the DCM extract has led to the isolation of Compound 1, pyochelin. Antimicrobial testing of Compound 1 was performed with 13 other test microorganisms via broth microdilution. Compound 1 demonstrated antimicrobial activity against four Staphylococcus strains and three Enterococcus strains; but not Bacillus subtilis ATCC 8188, B. cereus ATCC 14579 and all other 
TABLE 1 | Differentiation characteristics of strain $\mathrm{MSh1}^{\top}$ and type strains of closely related species of Bcc.

\begin{tabular}{|c|c|c|c|c|c|c|c|c|c|c|c|c|c|c|c|c|c|c|c|c|}
\hline Characteristics & 1 & 2 & 3 & 4 & 5 & 6 & 7 & 8 & 9 & 10 & 11 & 12 & 13 & 14 & 15 & 16 & 17 & 18 & 19 & 20 \\
\hline \multicolumn{21}{|l|}{ ACIDIFICATION OF } \\
\hline Sucrose & + & + & + & - & + & - & + & - & + & v & + & + & + & + & + & + & + & - & - & - \\
\hline Adonitol & - & + & + & + & v & + & - & + & + & v & + & - & + & v & + & + & + & + & + & + \\
\hline \multicolumn{21}{|l|}{ ASSIMILATION OF } \\
\hline N-acetyl-glucosamine & - & + & + & + & + & + & + & + & + & + & + & + & + & + & + & + & + & + & + & + \\
\hline \multicolumn{21}{|c|}{ ENZYMATIC ACTIVITY OF } \\
\hline Arginine decarboxylation & + & - & - & - & - & - & - & - & - & - & - & + & - & - & - & - & - & - & - & - \\
\hline Lysine decarboxylation & + & + & + & + & + & + & + & - & + & v & + & - & + & + & v & + & + & v & + & - \\
\hline$\beta$-galactosidase & - & + & + & - & + & - & + & + & + & v & + & - & + & + & + & + & + & + & + & + \\
\hline \multicolumn{21}{|l|}{ FATTY ACID CONTENT } \\
\hline $\mathrm{C}_{16: 0}(\%)$ & 31.7 & 29.8 & 36.5 & 28.2 & 26.8 & 25.6 & 19.5 & 26.1 & 26.3 & 28.4 & 22.9 & 16.6 & 17.8 & 21.2 & 28.1 & 26.4 & 21.9 & 28.9 & 20.9 & 29.0 \\
\hline $\mathrm{C}_{17: 0 \text { cyclo }(\%)}$ & 26.6 & 22.5 & 26.1 & 23.5 & 17.9 & 17.8 & 14.0 & 16.0 & 11.3 & 4.6 & 13.5 & 5.7 & 12.6 & 1.6 & 11.7 & 10.4 & 5.2 & 18.2 & 8.0 & 17.2 \\
\hline $\mathrm{C}_{19: 0}$ cyclo $\omega 8 \mathrm{c}(\%)$ & 16.5 & 13.7 & 17.6 & 19.8 & 12.5 & 15.3 & 5.8 & 14.8 & 4.8 & 1.3 & 4.7 & 2.4 & 9.5 & 0.4 & 1.6 & 3.0 & 1.8 & 9.7 & 4.2 & 10.0 \\
\hline
\end{tabular}

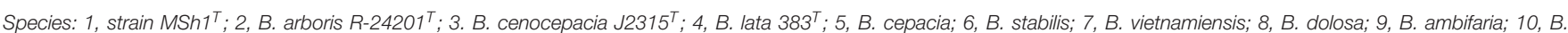
anthina; 11, B. pyrrocinia, 12, B. ubonensis; 13, B. latens; 14, B. diffusa; 15, B. seminalis; 16, B. metallica; 17, B. contaminans; 18; B. multivorans; 19, B. pseudomultivorans; 20, B. gladioli.

Data for strain MSh1 ${ }^{T}$, B. arboris R-24201 ${ }^{T}$, B. cenocepacia $J 2315^{T}$, and B. lata $383^{T}$ are from this study. Data for the other Bcc species were obtained from Coenye et al. (2001),

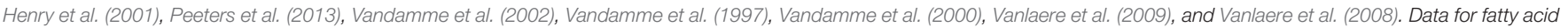
content are percentages of whole-cell fatty acid content.,$+>90 \%$ of all isolate positive; $v, 10-90 \%$ position; -, $<10 \%$ of strains positive.

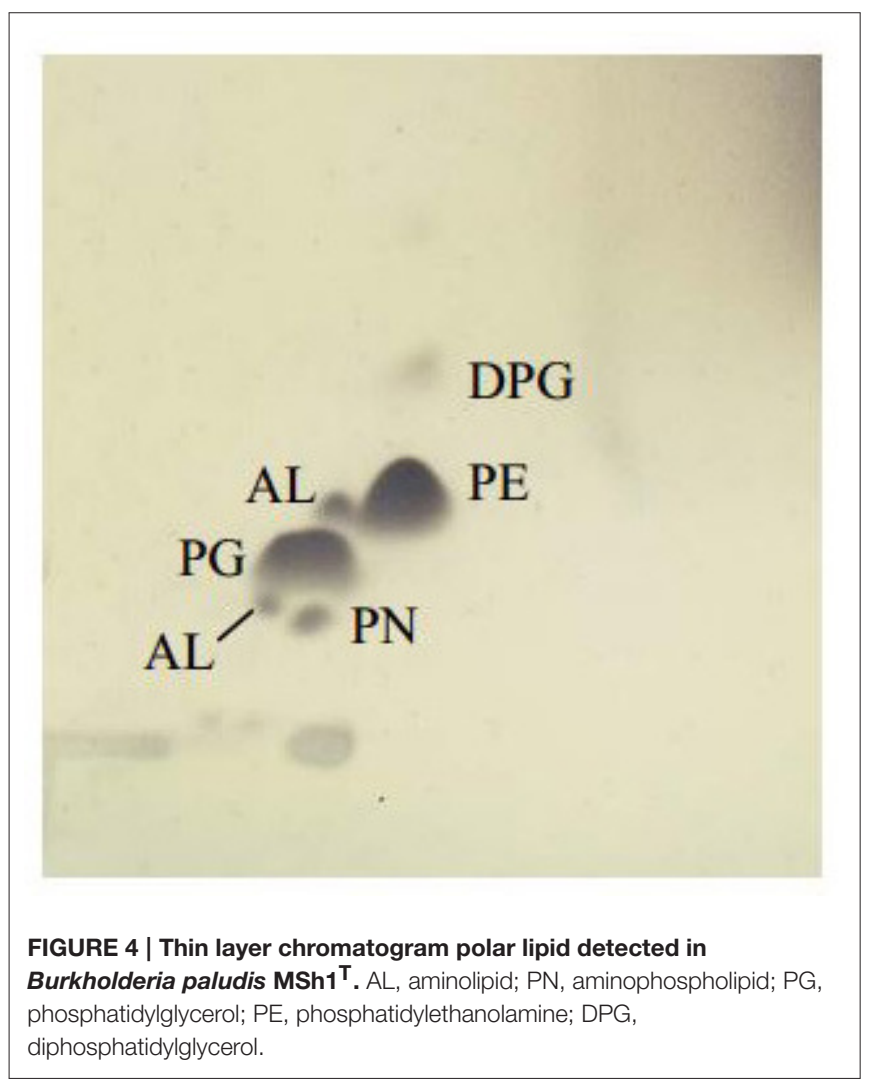

Gram negative bacteria tested. SEM analysis showed that the cellular morphology of E. faecalis ATCC 700802 was not affected by pyochelin.

\section{DISCUSSION}

The taxonomic position of strain $\mathrm{MSh}^{\mathrm{T}}$ was determined and characterized using a polyphasic approach. The $16 \mathrm{~S}$ rRNA sequence of strain $M S h 1^{\mathrm{T}}$ revealed that it belonged to the genus Burkholderia and was closely related to the Bcc. Phylogenetic analysis further showed that strain $\mathrm{MSh}^{\mathrm{T}}$ clades closely to $B$. arboris, B. lata and B. cenocepacia. Despite having high $16 \mathrm{~S}$ rRNA gene sequence similarity (data not shown), phylogenetic analysis indicated that strain $\mathrm{MSh}^{\mathrm{T}}$ is situated on a different branch in the tree, signifying the possibility of being a novel species. As members of Bcc are known to have high similarity in terms of $16 \mathrm{~S}$ rRNA gene sequence, other molecular taxonomy techniques have to be used to differentiate and identify them (Coenye and Vandamme, 2003; Spilker et al., 2009; Peeters et al., 2013). Hence, DDH and MLSA were performed in this study. The DDH results which showed that the DNADNA relatedness value between strain $\mathrm{MSh}^{\mathrm{T}}$ and its closely related neighbors (based on 16S rRNA phylogenetic analysis) were below the 70\% threshold value for species delineation (Wayne et al., 1987). This was further supported by the average concatenated allele sequence divergence (obtained from the MLSA analysis) of strain $\mathrm{MSh}^{\mathrm{T}}$ toward other Bcc species which were above the 3\% threshold (Librado and Rozas, 2009). Moreover, based on the biochemical profile of strain $\mathrm{MSh}^{\mathrm{T}}$, it can be distinguished from most Bcc by its inability to assimilate $\mathrm{N}$-acetyl-glucosamine. Furthermore, this study has used a combination of both polyphasic and genome comparison (via next generation sequencing) to determine the species delineation of strain $M S h 1^{\mathrm{T}}$. For every technique used, each result revealed that strain $M S h 1^{\mathrm{T}}$ is indeed a novel species within the Bcc. 
TABLE 2 | Comparison of gene clusters responsible for secondary metabolites biosynthesis between strain MSh1 with related Burkholderia species.

\begin{tabular}{|c|c|c|c|c|c|c|c|c|}
\hline Burkholderia strains & Genome size (Mbp) & PKS & NRPS & Hybrid & Bacteriocin & Putative & Others & Total \\
\hline Burkholderia sp. MSh1 & 8.63 & 1 & 1 & 1 & 4 & 29 & 7 & 43 \\
\hline B. ambifaria AMMD & 7.64 & 1 & 2 & 2 & 2 & 0 & 12 & 19 \\
\hline B. cenocepacia J2315 & 8.06 & 1 & 3 & 0 & 1 & 0 & 8 & 13 \\
\hline B. cepacia GG4 & 6.47 & 1 & 1 & 0 & 1 & 0 & 5 & 8 \\
\hline B. lata sp. 383 & 8.68 & 1 & 2 & 0 & 2 & 0 & 8 & 13 \\
\hline B. multivorans ATCC 17616 & 7.01 & 1 & 1 & 0 & 1 & 0 & 10 & 13 \\
\hline B. pyrrocinia $\mathrm{CH}-67$ & 8.04 & 1 & 3 & 2 & 3 & 0 & 10 & 19 \\
\hline B. ubunensis Bu & 6.93 & 0 & 4 & 1 & 3 & 0 & 17 & 25 \\
\hline B. vietnamiensis G4 & 8.39 & 0 & 1 & 0 & 1 & 0 & 7 & 9 \\
\hline
\end{tabular}

PKS, polyketide synthase; NRPS, non-ribosomal polyketide synthethase; hybrid, combination of PKS and NRPS.

TABLE 3 | The minimum inhibitory concentration (MIC) of different fractions and crude methanol extract against the five test microorganism strains.

\begin{tabular}{lccccc}
\hline \multirow{2}{*}{ Test microorganism } & \multicolumn{5}{c}{ MIC (mg/ml) } \\
\cline { 2 - 6 } & CME & HEX & DCM & EtOAC & Water \\
\hline E. faecalis ATCC 29212 & 0.020 & $>5.000$ & 0.020 & 0.313 & 0.156 \\
E. faecalis ATCC 700802 & 0.039 & $>5.000$ & 0.039 & 0.313 & 0.313 \\
S. aureus ATCC 29213 & 0.313 & $>5.000$ & 0.313 & 2.500 & 1.250 \\
S. aureus ATCC 700699 & 0.156 & $>5.000$ & 0.156 & 1.250 & 1.250 \\
E. coli ATCC 25922 & 2.500 & $>5.000$ & 2.500 & 1.250 & 1.250
\end{tabular}

CME, Crude methanol extract; HEX, Hexane fraction; DCM, Dichloromethane fraction; EtOAc, Ethyl acetate.

The genus Burkholderia is well known for producing a wide range of secondary metabolites which include siderophores (Asghar et al., 2011), antifungal (Lu et al., 2009; Tawfik et al., 2010), antibacterial (El-Banna and Winkelmann, 1998; Mitchell and Teh, 2005; Mitchell et al., 2008), antitumor (Klausmeyer et al., 2011; He et al., 2014), and exotoxins (Jeong et al., 2003; Partida-Martinez and Hertweck, 2007). Secondary metabolites are compounds which are non-essential for microbial growth or reproduction but provide diverse survival functions in nature (Martin et al., 2005). Many of these secondary metabolites are regulated by complex synthesis mechanisms within the bacteria itself which include the PKS and NRPS. The assembly of a polyketide via the PKS system begins by priming the starter molecule to a catalytic domain, followed by chain elongation with extender units by different kind of enzymes. As for the NRPS system, a NRP will firstly be generated and then linked with other molecules for instance a phosphate group, methyl group or fatty acids (Donadio et al., 2007; Amoutzias et al., 2008). In this present study, antiSMASH was used to annotate the secondary metabolite biosynthetic gene clusters present in the draft genome of strain $M S h 1^{\mathrm{T}}$. It was found that strain $M S h 1^{\mathrm{T}}$ has a higher number of secondary metabolite biosynthetic gene clusters as compared to other known antimicrobial producing Bcc species, for example B. cepacia and B. pyroccinia (Souza and Raaijmakers, 2003). Both PKS and NRPS gene clusters are present in the genome, indicating the antimicrobial compounds produced might be assembled by either of these two gene clusters. Moreover, strain $\mathrm{MSh}^{\mathrm{T}}$ might be able to produce a more complex antimicrobial compound as a hybrid PKS-NRPS was annotated by antiSMASH. One example of such an antimicrobial compound is a lipopeptide class compound (Sorensen et al., 2014). Lipopeptides are antimicrobial compounds, known to disrupt the surface membrane charges of its target. Thus far, there have been only two reported lipopeptides (burkholdine and occidiofungin) produced by Bcc species and they only possess antifungal activity ( $\mathrm{Lu}$ et al., 2009; Tawfik et al., 2010). Bacteriocins are small peptides with narrow-spectrum antimicrobial properties (Cotter et al., 2013). Capistruin, is an example of antimicrobial peptide produced by a Burkholderia species. Nevertheless, the antimicrobial activity is only limited to several Gram negative bacteria which include Burkholderia species, Psuedomonas aeruginosa, and E. coli (Knappe et al., 2008). The data obtained from antiSMASH provided a preliminary insight into the secondary metabolite gene clusters present in the genome of strain $M S h 1^{\mathrm{T}}$ and it is certain that strain $\mathrm{MSh}^{\mathrm{T}}$ can indeed produce antimicrobial compounds. As many secondary metabolite biosynthetic gene clusters were present in the genome, the antimicrobial activity observed might be due to the presence of multiple compounds. Therefore, extraction of the antimicrobial compounds produced by strain $\mathrm{MSh}^{\mathrm{T}}$ was performed in this study.

Since the antimicrobial activity of strain $\mathrm{MSh}^{\mathrm{T}}$ was determined with agar overlay assay in the previous study (Ong et al., 2015), this showed that the antimicrobial compounds produced could be extracted from the agar itself. Therefore, agar extraction (solid-liquid extraction) was carried out. This technique was adopted from a study conducted by Isnansetyo and Kamei (2003) in which they successfully extracted an antimicrobial compound produced by Pseudoalteromonas phenolica cultured on marine solid media. It was shown that E. faecalis ATCC 29212 and E. faecalis ATCC 700802 were highly sensitive to the antimicrobial compounds with MIC-value of $0.020 \mathrm{mg} / \mathrm{ml}$ and $0.039 \mathrm{mg} / \mathrm{ml}$, respectively, as compared to S. aureus ATCC $29213(0.313 \mathrm{mg} / \mathrm{ml})$, S. aureus ATCC 700699 $(0.156 \mathrm{mg} / \mathrm{ml})$ and E. coli ATCC $25922(2.500 \mathrm{mg} / \mathrm{ml})$ (consistent 
with Ong et al., 2015). To the best of our knowledge, there has only been one antimicrobial compound with inhibitory effect against Gram positive bacteria and fungus (pyrrolnitrin), isolated from Burkholderia species, and based on the PCR performed in this study, the prnD gene was not found in strain MSh $1^{\mathrm{T}}$ which further substantiate that it might be producing other types of antimicrobial compounds. Furthermore, the genes that code for $\operatorname{prn} A, \operatorname{prn} B, \operatorname{prn} C$ and $p r n D$ were absent from the draft genome of strain $\mathrm{MSh}_{1}{ }^{\mathrm{T}}$.

Sequential solvent fractionation was performed to fractionate and partially purify, at the same time removing impurities present in the crude methanol extract. A similar method was adopted from Tawfik et al. (2010) to isolate antifungal burkholdines produced by B. ambifaria $2.2 \mathrm{~N}$. In this study, four different solvents were used: hexane (HEX), dichloromethane (DCM), ethyl acetate (EtOAc) and water. HEX is a non-polar solvent commonly used to remove non-polar compounds from the crude extract. DCM and EtOAc both have middle-range polarity, thus is able to attract a wider range of compounds with different polarity (Moreau et al., 2003). Water being the most polar solvent will retain any compounds with highly polarity (Wang and Weller, 2006). It was shown that the HEX fraction had no antimicrobial activity against all test microorganisms up to $5 \mathrm{mg} / \mathrm{mL}$. The DCM fraction had the best antimicrobial activity against all the test microorganism strains (when compared with the EtOAc and water fractions) as the MIC-values were comparable or similar to the crude methanol extract (Table 3). Thus, further purification was conducted on the DCM fraction using $\mathrm{C}_{18}$ which led to the isolation of Compound 1. Chromatographic analysis of Compound 1 on a TLC plate with chloroform-acetic acidethanol at 90:5:2.5 (v/v) as the mobile phase showed one spot $\left(R_{\mathrm{f}} 0.35\right)$ with yellow-green fluorescent band that turned red-brown after spraying with the iron reagent. Analysis of Compound 1 by analytical HPLC indicated that the compound contained one peak with three maxima at 210, 270, and 320 $\mathrm{nm}$. The mass of Compound $1\left(\mathrm{~m} / z \quad 325,[M+\mathrm{H}]^{+}\right)$was determined by liquid chromatography-electrospray ionizationmass spectrometer (LC-ESI-MS). The ESI-MS indicated that the molecular formula of the compound was $\mathrm{C}_{14} \mathrm{H}_{16} \mathrm{~N}_{2} \mathrm{O}_{3} \mathrm{~S}_{2}$. The interpretation of ESI-MS and UV spectrum of Compound 1 were found to be identical to pyochelin which was in good agreement with previous literature (Cox et al., 1981; Adler et al., 2012) (Figures S1, S2).

Pyochelin is a type of siderophore commonly produced by the genus Pseudomonas (Cox et al., 1981; Buysens et al., 1996; Lim et al., 2016). Siderophores can solubilize ferric ion, hence is an iron chelating growth factor for many bacteria. Thus far, only three Burkholderia species (B. arboris, B. cenocepacia and $B$. contaminans) have been known to produce pyochelin (Dang et al., 2011; Schwagner et al., 2012; Deng et al., 2015). As pyochelin is a siderophore, its antimicrobial properties were not extensively studied. Pyochelin can inhibit or kill bacteria by catalyzing the generation of reactive oxygen species (ROS) (Adler et al., 2012). However, this is bacteria dependent as shown in Table 4. The Gram negative bacteria (typically the Enterobacteriaceae) were found to be resistant to Compound
TABLE 4 | The minimum inhibitory concentration (MIC) of Compound 1 (pyochelin) against 18 test microorganisms.

\begin{tabular}{|c|c|c|}
\hline Gram stain & Bacteria strains & $\operatorname{MIC}(\mu \mathrm{g} / \mathrm{ml})$ \\
\hline \multirow[t]{9}{*}{ Gram positive } & Bacillus cereus ATCC 14579 & $>100.00$ \\
\hline & Bacillus subtilis ATCC 8188 & $>100.00$ \\
\hline & Enterococcus faecalis ATCC 700802 & 3.13 \\
\hline & Enterococcus faecalis ATCC 29212 & 3.13 \\
\hline & Enterococcus faecalis $\mathrm{JH}-22$ & 3.13 \\
\hline & $\begin{array}{l}\text { Staphylococcus aureus ATCC } \\
700699\end{array}$ & 6.26 \\
\hline & Staphylococcus aureus ATCC 43300 & 6.26 \\
\hline & Staphylococcus aureus ATCC 6538P & 6.26 \\
\hline & Staphylococcus aureus ATCC 29213 & 6.26 \\
\hline \multirow[t]{9}{*}{ Gram negative } & Aeromonas hydrophila ATCC 49140 & $>100.00$ \\
\hline & Escherichia coli ATCC 25922 & $>100.00$ \\
\hline & Klebsiella pneumoniae ATCC 10031 & $>100.00$ \\
\hline & Proteus mirabilis ATCC 49140 & $>100.00$ \\
\hline & Proteus vulgaris IMR & $>100.00$ \\
\hline & $\begin{array}{l}\text { Pseudomonas aeruginosa ATCC } \\
10145\end{array}$ & $>100.00$ \\
\hline & $\begin{array}{l}\text { Pseudomonas aeruginosa ATCC } \\
\text { BAA- } 47\end{array}$ & $>100.00$ \\
\hline & Salmonella Typhimurium ATCC 14028 & $>100.00$ \\
\hline & Shigella flexneri ATCC 12022 & $>100.00$ \\
\hline
\end{tabular}

1 (pyochelin) and this is consistent with the study conducted by Adler et al. (2012). The resistant profile shown by the Enterobacteriaceae was due to the production of catecholate siderophores such as enterobactin. These siderophores can act as hydrogen atom donors and efficiently terminate radical chain reactions; hence rendering pyochelin ineffective. The inhibitory effect of pyochelin on the four $S$. aureus and three E. faecalis strains might due to presence of ROS generated by pyochelin. Nevertheless, no literature has reported on the downstream effect of the ROS produced by pyochelin, as it might target the DNA/RNA replication, electron transport chain or bacterial cell membrane. Moreover, the nutrient availability of these strains might be compromised as pyochelin can chelate the vital metal ions present in the environment. Consequently, these sensitive strains might be starved and ultimately led to death, as they lack the receptors to mediate the entry of metal-bounded pyochelin into the bacterial cells. Hence as a preliminary study, we investigated the effect of pyochelin on the cellular morphology of E. faecalis ATCC 700802 via SEM. Pyochelin did not affect the cellular morphology of E. faecalis ATCC 700802, when compared to the positive control in which the morphology of the bacteria were distorted when treated with $100 \mu \mathrm{g} / \mathrm{ml}$ of chloramphenicol (Figure 5). This result supports that the ROS generated by pyochelin might target the intracellular components of E. faecalis ATCC 700802. Further work on the effect of pyochelin on the DNA/RNA replication will be validated via qPCR in the future. Moreover, the antimicrobial activity of pyochelin was not only restricted to normal strains of $S$. aureus and E. faecalis, but it also affects the antimicrobialresistant strains, for instance methicillin-resistant $S$. aureus 

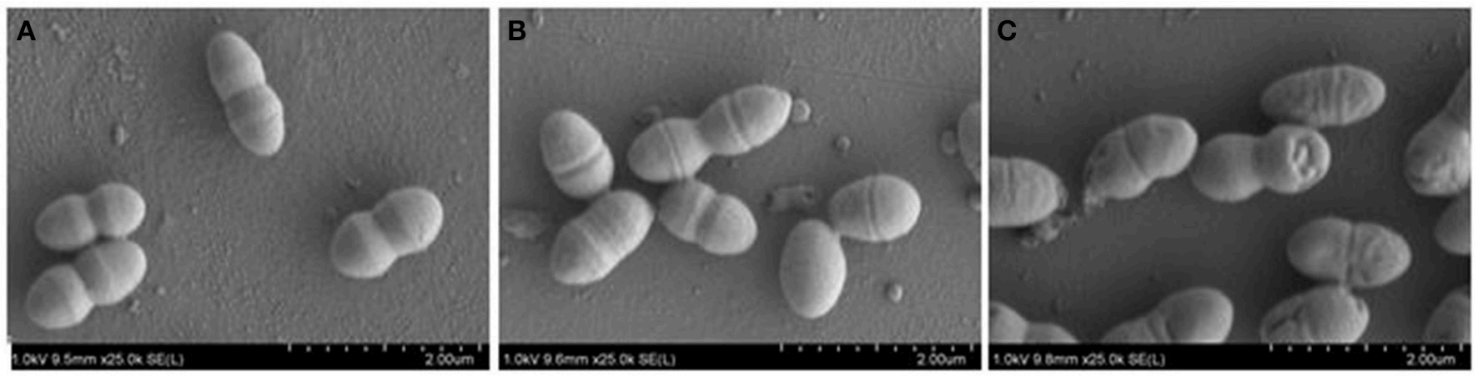

FIGURE 5 | FE-SEM images of E. faecalis ATCC 700802 showing (A) negative control, (B) treated with MIC of Compound 1 and (C) treated with $100 \mu \mathrm{g} / \mathrm{ml}$ of chloramphenicol (positive control). Images were taken under 5000x magnification at $1 \mathrm{kV}$.

ATCC 700699, methicillin-resistant S. aureus ATCC 43300 and vancomycin-resistant E. faecalis ATCC 700802. However, this has to be validated by increasing the number of test strains used. Additional work is on-going to further elucidate the downstream effect of pyochelin on these sensitive strains, and also to determine its potential synergistic action with antibiotics. Nevertheless, this study has provided an insight that the infamous pyochelin might potentially be used to treat infections caused by ARB.

Based on the results of phylogenetic analysis, DDH, MLSA, GGDC, ANI, phenotypic, chemotaxonomic and biochemical characterization, strain $\mathrm{MSh}^{\mathrm{T}}$ was assigned to a novel species in the genus Burkholderia, for which the name Burkholderia paludis sp. nov. is proposed.

\section{Description of Burkholderia paludis sp. nov.}

Burkholderia paludis (pa.lu.dis. L. gen. n. paludis of the swamp). Cells are Gram negative, facultative anaerobic, motile rods, about $0.6-0.8 \mu \mathrm{m}$ wide and 1.6-2.1 $\mu \mathrm{m}$ long. Colonies are regular, circular, convex, translucent, moist and 1.0$3.0 \mathrm{~mm}$ in diameter after 2 days of cultivation at $30^{\circ} \mathrm{C}$ on NA. Grows at $15-40^{\circ} \mathrm{C}$ (optimum $30^{\circ} \mathrm{C}$ ) and $\mathrm{pH} 4.0_{-}$ 10.0 (optimum $\mathrm{pH} 7.0$ ) in $\mathrm{NB}$. Grows at $0-2.5 \% \mathrm{NaCl}$ (optimum without $\mathrm{NaCl}$ ). Cells are positive for oxidase, glucose fermentation, arginine dihydrolase, urease, esculin hydrolysis and assimilation of glucose, but negative for nitrate/nitrite reduction, indole production, gelatin hydrolysis, $\beta$-galactosidase, assimilation of arabinose, mannose, mannitol, $\mathrm{N}$-acetyl-glucosamine, maltose, potassium gluconate, capric acid, adipic acid, malate, trisodium citrate and phenylacetic acid (API 20NE).

In API ZYM-tests, positive for alkaline phosphatase, esterase (C4), esterase lipase (C8), leucine arylamidase, acid phosphatase, naphthol-AS-BI-phosphohydrolase, $\beta$-glucosidase and $n$-acetyl- $\beta$-glucosaminidase, but negative for valine arylamidase, cystine arylamidase, trypsin, a-chymotrypsin, $\alpha$-galactosidase, $\beta$-galactosidase, $\beta$-glucoronidase, $\alpha$-glucosidase, $\alpha$ mannosidase and $\alpha$-fucosidase. The following carbon sources are utilized in the API 50CH: glycerol, erythritol, D-arabinose, $\mathrm{L}$-arabinose, ribose, $\mathrm{D}$-xylose, galactose, $\mathrm{D}$-glucose, $\mathrm{D}$-fructose,
D-mannose, dulcitol, inositol, mannitol, sorbitol, $\alpha$-methylD-glucoside, arbutin, esculin, salicin, cellobiose, maltose, lactose, saccharose, trehalose, D-turanose, D-xylose, D-tagatose, D-fucose, L-fucose, D-arabitol and L-arabitol; the other substrates, L-xylose, adonitol, $\alpha$-methyl-D-xiloside, L-sorbose, rhamnose, $\alpha$-methyl-D-mannoside, $\alpha$-methyl-D-glucosamine, amygdalin, melibiose, inulin, melezitose, D-raffinose, amidon, glycogen, xylitol, $\beta$-gentiobiose, gluconate, 2-keto-gluconate and 5-keto-gluconate, are not utilized.

The fatty acid profile is composed mainly of $\mathrm{C}_{16: 0}(31.7 \%)$, $\mathrm{C}_{17: 0}$ cyclo $(26.6 \%)$, and $\mathrm{C}_{19: 0}$ cyclo $\omega 8 \mathrm{c}(16.1 \%)$. The major compounds in the polar lipid profile are phosphatidylglycerol, phosphatidylethanolamine and diphosphatidylglycerol. The predominant ubiquinone is Q-8. Strain $M S h 1^{\mathrm{T}}$ is able to produce antimicrobial compounds active against four strains of $S$. aureus and three strains of E. faecalis.

The type strain is $\mathrm{MSh}^{\mathrm{T}}$ (=DSM $100703^{\mathrm{T}}=\mathrm{MCCC}$ $\left.1 \mathrm{~K} 01245^{\mathrm{T}}\right)$, isolated from surface peat from the Southeast Pahang tropical peat swamp forest reserve, Malaysia. The 16S rRNA and MLSA gene sequence of strain $\mathrm{MSh}^{\mathrm{T}}$ has been deposited in GenBank/EMBL/DDBJ under the accession number KT159931 and KU301866-301872, respectively.

\section{ACCESSION NUMBERS}

The GenBank/EMBL/DDBJ accession number for the $16 \mathrm{~S}$ rRNA gene sequence of strain $\mathrm{MSh}^{\mathrm{T}}$ is KT159931. The GenBank/EMBL/DDBJ accession number for the MLSA gene sequences of strain MSh1 ${ }^{\mathrm{T}}$ are KU301866-301872.

\section{AUTHOR CONTRIBUTIONS}

KSO performed the laboratory experiments, data analysis and the manuscript write-up. SML supervised the entire study. LHL and YLC co-supervised the study. SML, KSO and YKA contributed to the experimental designs. LHL and KSO contributed to the polyphasic taxonomy. CMY, SML and YKA apprehended the idea of bioprospecting in tropical peat swamp forest. All authors proofread and reviewed the manuscript. 


\section{ACKNOWLEDGMENTS}

The authors would like to thank the School of Science and Tropical Medicine and Biology Multidisciplinary Platform, Monash University Malaysia for funding this project.

\section{REFERENCES}

Adler, C., Corbalán, N. S., Seyedsayamdost, M. R., Pomares, M. F., de Creistóbal, R. E., Clardy, J., et al. (2012). Catecholate siderophores protect bacteria from pyochelin toxicity. PLOS ONE 7:e46754. doi: 10.1371/journal.pone.00 46754

Ammerlaan, H. S., Harbarth, S., Buiting, A. G., Crook, D. W., Fitzpatrick, F., Hanberger, H., et al. (2016). Secular trends in nosocomiam bloodstream infections: antibiotic-resistant bacteria increase the total burden of infection. Clin. Infect. Dis. 56, 798-805. doi: 10.1093/cid/cis1006

Amoutzias, G. D., Van de Peer, Y., and Mossialos, D. (2008). Evolution and taxanomic distribution of nonribosomal peptide and polyketide synthase. Future Microbiol. 3, 361-370. doi: 10.2217/17460913.3.3.361

Asghar, A. H., Shastri, S., Dave, E., Wowk, I., Agnoli k., Cook, A. M., et al. (2011). The pobA gene of Burkholderia cenocepacia encodes a Group I Sfp-type phosphopantetheinyltransferase required for biosynthesis of the siderophores ornibactin and pyochelin. Microbiology 157, 349-361. doi: 10.1099/mic.0.045559-0

Blin, K., Kazempour, D., Wohlleben, W., and Weber, T. (2014). Improved lanthipeptide detection and prediction for antiSMASH. PLOS ONE 9:e89420. doi: 10.1371/journal.pone.0089420

Blin, K., Medema, M. H., Kazempour, D., Fischbach, M. A., Breitling, R., Takano, E., et al. (2013). antiSMASH 2.0: a versatile platform for genome mining for secondary metabolite producers. Nucleic Acids Res. 41, 204-212. doi: 10.1093/nar/gkt449

Buck, J. D. (1982). Nonstaining (KOH) method for determination of Gram reactions of marine bacteria. Appl. Environ. Microbiol. 44, 992-993.

Bull, A. T., and Stach, J. E. (2007). Marine actinobacteria: new opportunities for natural product search and discovery. Trends. Microbiol. 15, 491-499. doi: 10.1016/j.tim.2007.10.004

Buysens, S., Heuengens, K., Poppe, J., and Hofte, M. (1996). Involvement of pyochelin and pyoverdin in suppression of Pythium-induced damping-off of tomato by Pseudomonas aeruginosa 7NSK2. Appl. Environ. Microbiol. 62, 865-871.

Caballero-Mellado, J. Martínez-Aguilar L., Paredes-Valdez, G., and Estradade los Santos, P. (2004). Burkholderia unamae sp. nov., an N2-fixing rhizospheric and endophtic species. Int. J. Syst. Evol. Microbiol. 54, 1165-1172. doi: 10.1099/ijs.0.02951-0

Cappuccino, J. G., and Sherman, N. (2002). Microbiology: A Laboratory Manual, 6th Edn. Menlo Park, CA: Benjamin Cummings.

Coenye, T., LiPuma, J. J., Henry, D., Hoste, B., Vandemeulebroecke, K., Gillis, M., et al. (2001). Burkholderia cepacia genomovar VI, a new member of the Burkholderia cepacia complex isolated from cystic fibrosis patients. Int. J. Syst. Evol. Microbiol. 51, 271-279. doi: 10.1099/00207713-51-2-271

Coenye, T., and Vandamme, P. (2003). Diversity and significance of Burkholderia species occupying diverse ecological niches. Environ. Microbiol. 5, 719-729. doi: 10.1046/j.1462-2920.2003.00471.x

Cotter, P. D., Ross, R. P., and Hill, C. (2013). Bacteriocins: a viable alternatie to antibiotics? Nat. Rev. Micriobiol. 11, 95-105. doi: 10.1038/nrmicro 2937

Cox, C. D., Rinehart, K. L. Jr., Moore, M. L., and Cook, C. (1981). Pyochelin: novel structure of an iron-chelating growth promoter for Pseudomonas aeruginosa. Proc. Natl. Acad. Sci. U.S.A. 78, 4256-4250. doi: 10.1073/pnas.78. 7.4256

Dang, L. D., Son, S. W., Cheon, H. M., Choi, G. J., Choi, Y. H., Jang, K. S., et al. (2011). Pyochelin isolated from Burkholderia arboris KRICT1 carried by pine wood nematodes exhibits phytotoxicity in pine callus. Nematology 13, 521-528. doi: $10.1163 / 138855410 \times 528271$

\section{SUPPLEMENTARY MATERIAL}

The Supplementary Material for this article can be found online at: http://journal.frontiersin.org/article/10.3389/fmicb. 2016.02046/full\#supplementary-material

De Ley, J., Cattoir, H., and Reynaerts, A. (1970). The quantitative measurement of DNA hybridization from renaturation rates. Eur. J. Biochem. 12, 133-142. doi: 10.1111/j.1432-1033.1970.tb00830.x

Deng, P., Wang, X., Baird, S. M., Showmaker, K. C., Smith, L., Peterson, D., et al. (2015). Comparative genome-wide analysis reveals that Burkholderia contaminans MS14 possesses multiple antimicrobial biosynthesis genes but not major genetic loci required for pathogenesis. Microbiol. Open 5, 353-369. doi: $10.1002 / \mathrm{mbo} 3.333$

Donadio, S., Monciardini, P., and Sosio, M. (2007). Polyketide synthase and nonribosomal peptide synthetases: the emerging view from bacterial genomics. Nat. Prod. Rep. 24, 1073-1109. doi: 10.1039/b514050c

El-Banna, N., and Winkelmann, G. (1998). Pyrrolnitrin from Burkholderia cepacia: antibiotic activity against fungi and novel activities against streptomycetes. J. Appl. Microbiol. 85, 69-78. doi: 10.1046/j.1365-2672.1998.00473.x

Felsenstein, J. (1985). Phylogenies and the comparative method. Am. Nat. 125, 1-15. doi: 10.1086/284325

Gillis, M., Van Van, T., Bardin, R., Goor, M., Hebbar, P., Willems, A., et al. (1995). Polyphasic taxonomy in the genus Burkholderia leading to an emended description of the genus and proposition of Burkholderia vietnamiensis sp. nov. for N2-fixing isolates from rice in Vietnam. Int. J. Syst. Evol. Microbiol. 45, 274-289. doi: 10.1099/00207713-45-2-274

Goris, J., Konstantinidis, K. T., Klappenbach, J. A., Coenye, T., Vandamme, P., and Tiedje, J. M. (2007). DNA-DNA hybridization values and their relationship to whole-genome sequence similarities. Int. J. Syst. Evol. Microbiol. 57, 81-91. doi: 10.1099/ijs.0.64483-0

He, H., Ratnayake, A. S., Janso, J. E., He, M., Yang, H. Y., Loganzo, F., et al. (2014). Cytotoxic spliceostatins from Burkholderia sp. and their semisynthetic analogues. J. Nat. Prod. 2014, 1864-1870. doi: 10.1021/np500342m

Henry, D., Mahenthiralingam, E., Vandamme, P., Coenye, T., and Speert, D. P. (2001). Phenotypic methods for determining genomovar status of the Burkholderia cepacia complex. J. Clin. Microbiol. 39, 1073-1078. doi: 10.1128/JCM.39.3.1073-1078.2001

Hibbing, M. E., Fuqua, C., Parsek, M. R., and Peterson, S. B. (2010). Bacterial competition: surviving and thriving in the microbial jungle. Nat. Rev. Micriobiol. 8, 15-25. doi: 10.1038/nrmicro2259

Huss, V. A. R., Festl, H., and Schleifer, K. H. (1983). Studies on the spectrophotometric determination of DNA hybridization from renaturation rates. Syst. Appl. Microbiol. 4, 184-192. doi: 10.1016/S0723-2020(83)8 0048-4

Imhoff, J. F., Labes, A., and Wiese, J. (2011). Bio-mining the microbial treasures of the ocean: new natural products. Biotechnol. Adv. 29, 468-482. doi: 10.1016/j.biotechadv.2011.03.001

Isnansetyo, A., and Kamei, Y. (2003). MC21-a, a bactericidal antibiotic produced by a new marine bacterium, Pseudoalteromonas phenolica sp. nov. O-BC30T, against methicillin-resistant Staphylococcus aureus. Antimicrob. Agents Chemother. 47, 480-488. doi: 10.1128/AAC.47.2.480488.2003

Jeong, Y., Kim, J., Kim, S., Kang, Y., Nagamatsu, T., and Hwang, I. (2003). Toxoflavin produced by Burkholderia glumae causing rice grain rot is responsible for inducing wilt in many field crops. Plant Dis. 87, 890-895. doi: 10.1094/PDIS.2003.87.8.890

Jukes, T., and Cantor, C. (1969). Evolution of protein molecules. Mamm. Protein. Metab. 3, 21-132. doi: 10.1016/B978-1-4832-3211-9. 50009-7

Kane, M. D., Poulsen, L. K., and Sathl, D. A. (1993). Monitoring the enrichment and isolation of sulfate-reducing bacteria by using oligonucleotide hybridization probes designed from environmentally derived $16 \mathrm{~S}$ rRNA sequences. Appl. Environ. Microbiol. 59, 682-686. 
Kimura, M. (1980). A simple method for estimating evolutionary rates of base substitutes through comparative studies of nucleotide sequences. J. Mol. Evol. 16, 111-120. doi: 10.1007/BF01731581

Klausmeyer, P., Shipley, S. M., Zuck, K. M., and McCloud, T. G. (2011). Histone deacetylase inhibitors from Burkholderia thailandensis. J. Nat. Prod. 74, 2039-2044. doi: 10.1021/np200532d

Knappe, T. A., Linne, U., Zirah, S., Rebuffat, S., XIe, X., and Marahiel, M. A. (2008). Isolation and structural characterization of capistruin, a lasso peptide predicted from the genome sequence of Burkholderia thailandensis E264. J. Am. Chem. Soc. 130, 11446-11454. doi: 10.1021/ja802966g

Librado, P., and Rozas, J. (2009). DnaSP v5: a software for comprehensive analysis of DNA polymorphism data. Bioinformatics 25, 1451-1452. doi: 10.1093/bioinformatics/btp187

Lim, C. K., Penesyan, A., Hassan, K. A., Loper, J. E., and Paulsen, I. T. (2016), Disruption of transporters affiliated with enantio-pyochelin biosynthesis gene cluster of Pseudomonas protegens Pf-5 has pleiotropic effects. PLoS ONE 11:e0159884. doi: 10.1371/journal.pone.0159884

Lu, S., Novak, J., Austin, F. W., Gu, G., Ellis, D., Kirk, M., et al. (2009). Occidiofungin, a unique antifungal glycopeptide produced by a strain of Burkholderia contaminans. Biochemistry 48, 8312-8321. doi: 10.1021/bi900814c

Martin, J. F., Casqueiro, J., and Liras, P. (2005). Secretion system for secondary metabolites: how producer cells send out messages of intercellular communication. Curr. Opin. Microbiol. 8, 282-293. doi: 10.1016/j.mib.2005. 04.009

Meier-Kolthoff, J. P., Auch, A. F., Klenk, H., and Göker, M. (2013). Genome sequence-based species delimitation with confidence intervals and improved distance functions. BMC Bioinformatics 14:60. doi: 10.1186/1471-2105$14-60$

Miller, L. T. (1982). A single derivatization method for bacterial fatty acid methyl esters including hydroxy acids. J. Clin. Microbiol. 16, 584-586.

Mishra, R. P., Oviedo-Orta, E., Prachi, P., Rappuoli, R., and Bagnoli, F. (2012). Vaccines and antibiotic resistance. Curr. Opin. Microbiol. 15, 1-7. doi: 10.1016/j.mib.2012.08.002

Mitchell, R. E., Greenwood, D. R., and Sarojini, V. (2008). An antibacterial pyrazole derivative from Burkholderia glumae, a bacterial pathogen of rice. Phytochemistry 69, 2704-2707. doi: 10.1016/j.phytochem.2008.08.013

Mitchell, R. E., and Teh, K. L. (2005). Antibacterial iminopyrrolidines from Burkholderia plantarii, a bacterial pathogen of rice. Org. Biomol. Chem. 3, 3540-3543. doi: 10.1039/b509319h

Moreau, R. A., Powell, M. J., and Singh, V. (2003). Pressurized liquid extraction of polar and nonpolar lipids in corn and oats with hexane, methylene chloride, isopropanol and ethanol. J. Am. Oil Chem. Soc. 80, 1063-1067. doi: 10.1007/s11746-003-0821-y

Ong, K. S., Aw, Y. K., Gan, H. M., Yule, C. M., and Lee, S. M. (2014). Draft genome sequences of two antimicrobial-producing Burkholderia sp. strains, MSh1 and MSh2, isolated from Malaysian tropical peat swamp forest soil. Genome. Announc. 2, 1-2. doi: 10.1128/genomeA.01032-14

Ong, K. S., Yule, C. M., and Lee, S. M. (2015). Antimicrobial producing bacteria isolated from tropical peat swamp soil. Malays. J. Microbiol. 11, 170-175. doi: 10.21161/mjm.12914

Partida-Martinez, L. P., and Hertweck, C. (2007). A gene cluster encoding rhizoxin biosynthesis in "Burkholderia rhizoxina", the bacterial endosymbiont of the fungus Rhizopus microsporus. Chembiochemistry 8, 41-45. doi: 10.1002/cbic.200600393

Peeters, C., Zlosnik, J. E., Spilker, T., Hird, T. J., LiPuma, J. J., and Vandamme, P. (2013). Burkholderia pseudomultivorans sp. nov., a novel Burkholderia cepacia complex species from human respiratory samples and the rhizosphere. Syst. Appl. Microbiol. 36, 483-489. doi: 10.1016/j.syapm.2013. 06.003

Pilsczek, F. H., Salina, D., Poon, K. K., Fahey, C., Yipp, B. G., Sibley, C. D., et al. (2010). A novel mechanism of rapid nuclear neutrophil extracellular trap formation in response to Staphylococcus aureus. J. Immunol. 185, 7413-7425. doi: 10.4049/jimmunol.1000675

Robbie, W. (1945). A hanging drop method for continuous observation of the activity of organisms in cyanide. Science 101, 649-650. doi: $10.1126 /$ science.101.2634.649
Saitou, N., and Nei, M. (1987). The neighbour-joining method: a new method for reconstructing phylogenetic trees. Mol. Bio. Evol. 4, 406-425.

Schwagner, S., Agnoli, K., Kothe, M., Feldmann, F., Givskov, M., Carlier, A., et al. (2012). Identification of Burkholderia cenocepacia strain H111 virulence factors using nonmammalian infections hosts. Infect. Immun. 81, 143-153. doi: 10.1128/IAI.00768-12

Sorensen, J. L., Sondergaard, T. E., Covarelli, L., Feuertes, P. R., Hansen, F. T., Frandsen, R. J. N., et al. (2014). Identification of the biosynthetic gene clusters for the lipopeptides Fusaristatin, A., and W493 B in Fusarium graminearum and F. pseudograminearum. J. Nat. Prod. 77, 2619-2625. doi: $10.1021 / \mathrm{np} 500436 \mathrm{r}$

Souza, J. T., and Raaijmakers, J. M. (2003). Polymorphisms within the prnD and pltC gene from pyrrolnitrin and pyoluteorin-producing Pseudomonas and Burkholderia spp. FEMS Microbiol. Ecol. 43, 21-34. doi: 10.1111/j.1574-6941.2003.tb01042.x

Spilker, T., Baldwin, A., Bumford, A., Dowson, C., Mahenthiralingam, E., and LiPuma, J. J. (2009). Expanded multilocus sequence typing for Burkholderia species. J. Clin. Microbiol. 47, 2607-2610. doi: 10.1128/JCM.00 770-09

Tamura, K., Peterson, D., Peterson, N., Stecher, G., Nei, M., and Kumar, S. (2011). MEGA5: molecular evolutionary genetics analysis using maximum likelihood, evolutionary distance, and maximum parsimony methods. Mol. Bio. Evol. 28 , 2731-2739. doi: 10.1093/molbev/msr121

Tawfik, K., Jess, P., Bray, B., Dubay, G., Falkinham, J. O., Mesbah, M., et al. (2010). Bukholdines 1097 and 1229, potent antifungal peptides from Burkholderia ambifaria 2.2N. Org. Lett. 12, 664-666. doi: 10.1021/ol90 29269

Thompson, J. D., Gibson, T. J., Plewniak, F., Jeanmougin, F., and Higgins, D. G. (1997). The CLUSTAL_X windows interface: flexible strategies for multiple sequence alignment aided by quality analysis tool. Nucleic Acids Res. 25, 4876-4882. doi: $10.1093 /$ nar/25.24.4876

Tindall, B. J. (1990). A comparative study of the lipid composition of Halobacterium saccharovorum from various sources. Syst. Appl. Microbiol. 13, 128-130. doi: 10.1016/S0723-2020(11)80158-X

Tindall, B. J., Sikorski, J., Smibert, R. M., and Kreig, N. R. (2007). "Phenotypic characterization and the principles of comparative systematics," in Methods for General and Molecular Microbiology, $3 r d$ Edn., eds C. A. Reddy, T. J. Beveridge, J. A. Breznak, G. Marzluf, T. M. Schmidt, and L. R. Snyder (Washington, DC: ASM Press), 330-393.

Vandamme, P., Henry, D., Coenye, T., Nzula, S., Vancanneyt, M., LiPuma, J. J., et al. (2002). Burkholderia anthina sp. nov. and Burkholderia pyrrocinia, two additional Burkholderia cepacia complex bacteria, may confound results of new molecular diagnostic tools. FEMS Immunol. Med. Microbiol. 33, 143-149. doi: 10.1111/j.1574-695X.2002.tb00584.x

Vandamme, P., Holmes, B., Vancanneyt, M., Coenye, T., Hoste, B., Coopman, R., et al. (1997). Occurrence of multiple genomovars of Burkholderia cepacia in cystic fibrosis patients and proposal of Burkholderia multivorans sp. nov. Int. J. Syst. Evol. Microbiol. 47, 1188-1200. doi: 10.1099/00207713-474-1188

Vandamme, P., Mahenthiralingam, E., Holmes, B., Coenye, T., Hoste, B., De Vos, P., et al. (2000). Identification and population structure of Burkholderia stabilis sp. nov. (formerly Burkholderia cepacia genomovar IV). J. Clin. Microbiol. 38, 1042-1047.

Vanlaere, E., Baldwin, A., Gevers, D., Henry, D., De Brandt, E., LiPuma, J. J., et al. (2009). Taxon, K., a complex within the Burkholderia cepacia complex, comprises at least two novel species, Burkholderia contaminans sp. nov. and Burkholderia lata sp. nov. Int. J. Syst. Evol. Microbiol. 59, 102-111. doi: 10.1099/ijs.0.001123-0

Vanlaere, E., LiPuma, J. J., Baldwin, A., Henry, D., Brandt, E., Mahenthiralingam, E., et al. (2008). Burkholderia latens sp. nov., Burkholderia diffusa sp. nov., Burkholderia arboris sp. nov., Burkholderia seminalis sp. nov. and Burkholderia metallica sp. nov., novel species within the Burkholderia cepacia complex. Int. J. Syst. Evol. Microbiol. 58, 1580-1590. doi: 10.1099/ijs.0. 65634-0

Wang, L., and Weller, C. L. (2006). Recent advances in extraction of nutraceuticals from plants. Trends Food Sci. Tech. 17, 300-312. doi: 10.1016/j.tifs.2005. 12.004 
Wang, Q., Song, F., Xiao, X., Huang, P., Li, L., Monte, A., et al. (2013). Abyssomicins from the South China Sea deep-sea sediment Verrucosispora sp.: natural thioether Michael addition adducts as antitubercular prodrugs. Angew. Chem. Int. Microbiol. 78, 2039-2042. doi: 10.1002/anie.201208801

Wayne, L. G., Brenner, D. J., Colwell, R. R., Grimont, P. A. D., Kandler, O., Krichevsky, M. I., et al. (1987). Report of the ad hoc committee on reconciliation of approaches to bacterial systematics. Int. J. Syst. Evol. Microbiol. 37, 463-464. doi: 10.1099/00207713-37-4-463

Yule, C. M. (2010). Loss of biodiversity and ecosystem functioning in IndoMalayan peat swamp forests. Biol. Conserv. 19, 393-409. doi: 10.1007/ s10531-008-9510-5
Conflict of Interest Statement: The authors declare that the research was conducted in the absence of any commercial or financial relationships that could be construed as a potential conflict of interest.

Copyright (๑) 2016 Ong, Aw, Lee, Yule, Cheow and Lee. This is an open-access article distributed under the terms of the Creative Commons Attribution License (CC BY). The use, distribution or reproduction in other forums is permitted, provided the original author(s) or licensor are credited and that the original publication in this journal is cited, in accordance with accepted academic practice. No use, distribution or reproduction is permitted which does not comply with these terms. 